\title{
Comparison of endonasal dacryocystorhinostomy (DCR) versus endocanalicular diode laser DCR for the treatment of nasolacrimal duct obstruction
}

\author{
Nazolakrimal kanal obstrüksiyonunun tedavisinde endonazal dakriyosistorinostomi (DSR) \\ ve endokanaliküler diyot lazer DSR'nin karşılaştırması
}

\author{
Mustafa Acar', Fatih Gören², Demet Yazıcl', Güven Yıldırım4, Turhan San \\ ${ }^{1}$ Department of Otorbinolaryngology, Yunus Emre Government Hospital, Eskişehir, Turkey \\ ${ }^{2}$ Department of Otorhinolaryngology, Sakarya Hospital, Eskişehir, Turkey \\ ${ }^{3}$ Department of Otorbinolaryngology, Tarsus Government Hospital, Tarsus, Mersin, Turkey \\ ${ }^{4}$ Department of Otorbinolaryngology, Okmeydan Training and Research Hospital, Istanbul, Turkey \\ ${ }^{5}$ Department of Otorbinolaryngology, Istanbul Medeniyet University Medical Faculty, Istanbul, Turkey
}

\begin{abstract}
Objective: Dacryocystorhinostomy (DCR), the treatment for nasolacrimal duct obstruction, is generally performed endonasally. In this retrospective study, we compared the anatomical and functional success rate of endonasal DCR with endocanalicular diode laser DCR.

Methods: Medical records of 53 patients in endonasal DCR group (Group 1) and 47 in endocanalicular diode laser DCR group (Group 2) were analyzed for preoperative syringing and probing evaluations as well as surgical details, outcomes and complications.

Results: Recurrence was observed in eight patients in Group 1 and six in Group 2. Although the recurrence rates differed between the two groups, this difference was not statistically significant $(\mathrm{p}>0.05)$. The complications in Group 1 included eight cases of synechia and one tube protrusion, whereas the complications in Group 2 included two cases of synechia, two tube protrusions and two punctum atrophies. The presence of allergy, concha hypertrophy and septum deviation did not significantly increase the rates of recurrence or complications $(p>0.05)$. Bleeding and pain were observed significantly more frequently in Group 1 and the patient comfort was significantly better in Group $2(\mathrm{p}<0.05)$.

Conclusion: Endocanalicular diode laser DCR was found to be a good alternative to endonasal DCR surgery thanks to better postoperative comfort, shorter healing time and less postoperative pain.
\end{abstract}

Keywords: Complication, dacryocystorhinostomy, diode laser, endocanalicular, endonasal.

\begin{abstract}
Özet
Amaç: Nazolakrimal kanal obstrüksiyonunun tedavisi olarak dakriyosistorinostomi (DSR) genellikle endonazal yoldan gerçekleştirilmektedir. Bu retrospektif çalışmada endonazal DSR ile endokanaliküler diyot lazer DSR'nin anatomik ve fonksiyonel başarı oranlarını karşılaştırdık.

Yöntem: Endonazal DSR grubunda 53 (Grup 1) ve endokanaliküler diyot lazer grubunda (Grup 2) 47 hastanın tıbbi kayıtları preoperatif enjeksiyon ve prob uygulamaları, cerrahi ayrıntılar, sonuçlar ve komplikasyonların değerlendirmesi açısından incelendi.

Bulgular: Grup 1'de 8 ve Grup 2'de 6 hastada nüks gözlemlendi. İki grup arasında nüks oranları farklılık göstermesine karşın bu farklılık istatistiksel açıdan anlamlı değildi (p>0.05). Grup 1'deki komplikasyonlar 8 sineşi ve 1 tüp protrüzyonu, Grup 2'de ise 2 sineşi, 2 tüp protrüzyonu ve 2 punktal atrofi olgusunu içermekteydi. Alerji, konka hipertrofisi ve septum deviasyonu nüks ve komplikasyon oranlarını anlamlı derecede artırmamıştı ( $>0.05)$. Grup 1'de kanama ve ağrı anlamlı derecede daha sık gözlenmiş olmasına rağmen Grup 2'de hasta konforu anlamlı derecede daha iyi idi $(\mathrm{p}<0.05)$.

Sonuç: Daha iyi postoperatif konfor, daha kısa iyileşme süresi ve daha az postoperatif ağriya neden olması sayesinde endokanaliküler diyot lazer DSR'nin endonazal DSR cerrahisine göre daha iyi bir alternatif olduğu saptanmıştır.
\end{abstract}

Anahtar sözcükler: Komplikasyon, dakriyosistorinostomi, diyot lazeri, endokanaliküler, endonazal.
Correspondence: Demet Yazıc1, MD. Department of Otorhinolaryngology, Tarsus Government Hospital, İsmetpaşa Mah., Tarsus, 33440, Mersin, Turkey.

e-mail: demetyazici@yahoo.com

Received: June 29, 2014; Accepted: September 3, 2014
Online available at: www.jmedupdates.org doi: 10.2399/jmu.2014003002 QR code: 
Nasolacrimal duct obstruction is frequently diagnosed in patients with a history of epiphora and discharge in the eyes. Dacryocystorhinostomy (DCR) is the treatment for nasolacrimal duct obstruction and can be performed externally or endonasally. ${ }^{[1]}$ External DCR which was first described by Toti in $1904^{[2]}$ is performed with a success rate of 82-99 percent. ${ }^{[3]}$ Fewer complications, such as cutaneous necrosis, cerebrospinal fluid leakage, maxillary and frontal sinusitis, retrobulbar hemorrhage, transient lagophthalmos and subcutaneous emphysema have been reported with this procedure ${ }^{[4,5]}$ However, this lengthy surgical procedure has many disadvantages, such as external skin incisional scarring, excessive intraoperative bleeding, disruption of the medial canthus anatomy and high morbidity associated with trauma to the anterior ethmoid, middle turbinate and nasal septum. ${ }^{[3,6]}$ The endonasal approach was first attempted in 1893 by Caldwell, ${ }^{[2]}$ which evolved into nasal endoscopy in the 1990s. With the development of modern nasal endoscopy, many techniques, most widely endonasal approach, have been used in endoscopic DCR. ${ }^{[7]}$

The advantages of endonasal DCR are the absence of external scarring with minimal postoperative hematoma formation, shorter postoperative recovery time, preservation of the pumping action on the orbicularis oculi muscle and simultaneous correction of intranasal abnormalities that can cause surgical failure, such as the formation of synechiae between the ostium and the septum or the middle turbinate. ${ }^{[8,9]}$

The disadvantages of the endonasal method are technical difficulties involved in visualizing the surgical site and achieving effective soft-tissue and bone removal, possibility of orbital perforation, multiple instrumentation inside the nose, insufficient size of the osteotomy cicatricial closure of the ostium, adhesions between the ostium and the middle turbinate, formation of synechiae between the ostium and the nasal septum, and granuloma formation within the ostium. ${ }^{(3,10-12]}$

There are different techniques and instruments employed in endonasal DCR. Bone removal can be achieved using the surgical drill, diamond-blurring, rongeur, hammer-chisel, radiofrequency or laser-assisted ablation. ${ }^{[2]}$

An endocanalicular multidiode laser with a 400-600 $\mu \mathrm{m}$ optical fiber, producing a wavelength of $980 \mathrm{~nm}$ with a power of 7-20 W was used in this study. It can ablate bone and soft tissues without causing excessive collateral damage. ${ }^{[13]}$ However, controversy remains as to which method is superior, considering that each method has advantages and disadvantages.

In this study we compared the anatomical and functional success rate of endonasal DCR with endocanalicular diode laser DCR.

\section{Materials and Methods}

This retrospective study compared the results of two centers that performed two different types of surgeries for the same purpose from December 2009 to July 2010. Group 1 consisted of 53 patients who had undergone endoscopic DCR and Group 2 of 47 patients receiving endocanalicular multidiode DCR. All patients were clinically evaluated by otorhinolaryngologists and ophthalmologists prior to surgery. The patients were selected among the cases who were admitted to the ophthalmology clinic with recurrent epiphora during a period of longer than six months and those with recurrent episodes of dacriocystitis. The nasolacrimal duct obstruction was diagnosed by nasolacrimal irrigation which fails to produce nasal drainage after syringing physiological saline into the canaliculus. Patients with significant sinus pathologies, concha bullosa or middle turbinate hypertrophy and patients who had undergone nasal surgeries, septoplasty or ethmoidectomy or any unsuccessful surgery for epiphora were excluded from the study.

The medical records of the patients were reviewed for preoperative and postoperative evaluation of syringing and probing including surgical details, clinical outcome and complications. The possible site of lacrimal obstruction was investigated by probing and syringing through both upper and lower canaliculi and the quality and quantity of the outflow through the opposite punctum were recorded.

\section{Endonasal DCR Surgery}

Endoscopic endonasal DCR was performed in Group 1 patients under general anesthesia. All surgeries were performed by an otorhinolaryngologist (M.A.) and an ophthalmologist (T.G.) at Yunus Emre State Hospital, Eskişehir, Turkey.

Patients were not premedicated preoperatively. The process was done endoscopically using 4-mm 0 - and 30degree angled rigid nasal endoscopes. After general anesthesia was administered, $20 \mathrm{mg} / \mathrm{mL}$ lidocaine hydrochloride $+0.0125 \mathrm{mg} / \mathrm{mL}$ epinephrine hydrochloride was applied submucosally around the uncinate process and the roof of the middle turbinate in order to decrease bleeding. The lacrimal sac was identified anterior to the uncinate process and inferior to the roof of the middle turbinate. The 
mucosa of this region was incised with a scalpel and elevated with a Freer elevator. The bone under this region was resected with Kerrison forceps and the medial and anterior aspects of the sac were exposed. Next, the medial aspect of the sac was incised with a scalpel or a sickle blade and the sac was opened into the nasal cavity. Punctums were dilated with a punctum dilator, the tops of the silicon cannula were orientated to the nasal passage and tied, and a pack was inserted into the operated side. The packing was removed two days later and after discharge nasal cleaning with physiological saline was recommended.

\section{Endocanalicular Multidiode Laser DCR}

Endocanalicular multidiode laser DCR applied to the patients in Group 2 under general anesthesia. All surgeries were performed by an otorhinolaryngologist (F.G.) and ophthalmologist (Z.E.) at Sakarya Hospital, Eskişehir, Turkey.

After the patient was monitored, a nasal pack soaked in a solution of 5\% pantocaine and 1:100,000 epinephrine was inserted through the middle meatus and removed at the beginning of the operation. Local anesthesia was applied by injecting the peribulbar area with lidocaine + marcaine solution. After canalicular dilatation, an endocanalicular diode laser probe of $600 \mu \mathrm{m}$ was inserted through the superior punctum to reach the lacrimal sac. The laser beam was reclined to the nasal bone using a nasal video endoscope controlled by the light of the laser. The light was directed to the medial aspect of the sac where the ostium was opened. The laser energy was applied to incise the lacrimal sac and the lacrimal bone through endocanalicular approach. Initially, a $0.5-\mathrm{cm}$ diameter osteotomy was made using $20 \mathrm{~W}$ shots of 550 pulse- 550 pause doses of the laser energy in contact with the lacrimal bone and nasal mucosa. The targeted area was washed with rifampicine solution and SF was applied via the canaliculus. In all cases, a silicone tube was guided under endoscopic visualization.

All patients in both groups used steroid-antibiotic combination eye drops four times a day, an analgesic (paracetamol three times a day) and steroid nasal spray two times a day for 4 weeks, postoperatively. Silicone tubes were removed at 4 to 6 months; thereafter, the aperture of the ostium was controlled by syringing of the canaliculus, performed by an ophthalmologist.

\section{Postoperative Follow-Up}

Patients received routine follow-up care at postoperative 3 rd day, 1st week, 1st, 3rd, 6th months, and 1st and 2nd years. The visual analogue scale (VAS) scores of wound healing time, intraoperative bleeding, postoperative pain and patient comfort were obtained from the patients files that were completed by patients and surgeons. Bleeding episodes were evaluated by the surgeons preoperatively and $12 \mathrm{~h}$ postoperatively and scored with VAS. Wound healing was evaluated by nasal endoscopy. The patients were observed regarding presence of edema, hyperemia, crust formation and ostial patency were observed.

\section{Statistical Analysis}

The anatomic and functional success of each case was compared using chi-square tests. The recurrence and complication ratios were controlled in the two groups. The relation of recurrence and complication with septum deviation, allergy and conchalhyperthrophy was evaluated. Perioperative or postoperative bleeding, postoperative pain and patient comfort were analyzed in the two groups.

\section{Results}

There were 84 females and 16 males in our series. Group 1 was composed of 53 patients (44 women and 9 men) with a mean age of 49 (range: 27 to 64) years. Group 2 was composed of 47 patients ( 40 women and 7 men) with a mean age of 54 (range: 26 to 73 ) years.

Recurrence and complication rates are presented in Table 2. Nine recurrences were observed in Group 1 (20.45\%) patients who underwent reoperations. Six recurrences were observed in Group 2 (14.63\%), whereas reoperation was considered in only two cases. This intergroup difference in recurrence rates was not statistically significant ( $p>0.05$ ). In a comparison of the two groups, recurrences were more frequent in patients who had symptoms during the 2-year-follow-up.

There were no serious complications such as orbital fat prolapse, cerebrospinal fluid leak, or delayed hemorrhage. Complications in Group 1 included eight cases of synechia formation between the lateral surface of the middle turbinate and the medial surface of the lateral wall of the nose and one case of protruded silicone tube. Complications in Group 2 included two synechia $(\mathrm{n}=2)$, punctum atrophy $(\mathrm{n}=2)$ and silicone tube protrusions $(\mathrm{n}=2)$ (Table 1$)$.

Nine patients in Group 1 had allergies and three of them had both recurrences and complications. Six patients in Group 2 had allergies; of these, one had only recurrence, two had both recurrences and complications (Table 2). 
Table 1. Complication types in Groups 1 and 2 ( $p>0.05)$.

\begin{tabular}{lcccc}
\hline Complication type & Synechia & Tube protrusion & Punctumatrophia & Total \\
\hline Group 1 & $8(88 \%)$ & $1(12 \%)$ & 0 & 9 \\
Group 2 & $2(33 \%)$ & $2(33 \%)$ & $2(33 \%)$ & 6 \\
\hline
\end{tabular}

Twelve patients in Group 1 had concha hypertrophy and six of them had both recurrences and complications. Twelve patients in Group 2 had concha hypertrophy and three of them had both recurrences and complications. The difference in recurrence and complication rates between groups was not statistically significant ( $p>0.05$ ) (Table 2).

Five patients in Group 1 had septum deviation and 2 of them had both recurrences and complications. Eight patients in Group 2 had septum deviation; and one of them had only recurrence, while the other patient had both recurrence and complication. The difference in recurrence and complication rates between groups was not statistically significant $(\mathrm{p}>0.05)$ (Table 2$)$.

In our study, preoperative and postoperative bleeding was significantly less in the laser group than in the endonasal group $(\mathrm{p}<0.05)$. Although wound healing appeared faster in the laser group, the difference between the groups was not statistically significant $(\mathrm{p}>0.05)$. Due to the smaller affected area and reduced surgical edema, Group 2 patients had less pain, with significantly lower pain VAS scores relative to the Group 1 patients $(\mathrm{p}<0.05)$. Moreover, packing was required in Group 1 patients to control bleeding which significantly increased patient discomfort when compared with Group 2 patients $(\mathrm{p}<0.05)$.

\section{Discussion}

Dacryocystitis is an infection of the nasolacrimal sac that usually results in an obstruction. It can be congenital or acquired and it is usually accompanied by epiphora. The obstruction may be congenital or develop within the first few weeks of life and a secondary dacryocystitis frequently develops. ${ }^{[14]}$ Congenital obstruction of the nasolacrimal system is present in approximately $5-6 \%$ of the newborns. ${ }^{[15]}$ Between $85-95 \%$ of the children who have uncomplicated congenital nasolacrimal duct obstruction experience spontaneous resolution by one year of age. ${ }^{[16]}$

Nasolacrimal obstruction may be controlled with probing or syringing performed through the canaliculus. Diagnostic evaluation of a patient may be achieved using computed tomography (CT), magnetic resonance imaging (MRI), ultrasonography and nasal endoscopy. CT and MRI are also helpful in differentiating a dacryocystocele from a medial canthal mass. ${ }^{[17]}$ Intubation dacryocystography is also a useful method to investigate the lacrimal drainage system in infants. It can be performed under topical anesthesia in the examination room. ${ }^{[18]}$

Lacrimal probing is considered as a first procedure in the treatment of nasolacrimal duct obstruction, with a success rate of approximately 90 percent. ${ }^{[19]}$ DCR is indicated when a common nasolacrimal duct obstruction is unresponsive to previous therapy. ${ }^{[7]}$

DCR can be achieved externally or endonasally. The complications associated with endonasal DCR differ from those commonly seen with the external approach. Complications of the endonasal approach tend to be more severe and include wound infection, bruising, scarring and punctual ectropion. ${ }^{[20]}$ Intraoperative complications of the endonasal approach are orbital fat prolapse, retrobulbar

Table 2. Relationships between recurrences and complications in terms of allergy, concha hypertrophy and septum deviation $(p>0.05)$

\begin{tabular}{|c|c|c|c|c|c|c|c|c|}
\hline & \multirow{2}{*}{\multicolumn{2}{|c|}{$\begin{array}{c}\text { Recurrences } \\
\text { Group } 1\end{array}$}} & \multirow{2}{*}{\multicolumn{2}{|c|}{$\begin{array}{c}\text { Complications } \\
\text { Group } 1\end{array}$}} & \multirow{2}{*}{\multicolumn{2}{|c|}{$\begin{array}{c}\text { Recurrences } \\
\text { Group } 2 \\
\end{array}$}} & \multirow{2}{*}{\multicolumn{2}{|c|}{$\begin{array}{c}\text { Complications } \\
\text { Group } 2\end{array}$}} \\
\hline & & & & & & & & \\
\hline & + & - & + & - & + & - & + & - \\
\hline Allergy & 3 & 6 & 3 & 6 & 3 & 3 & 2 & 4 \\
\hline Concha hypertrophy & 6 & 6 & 6 & 6 & 3 & 9 & 3 & 9 \\
\hline Septum deviation & 2 & 3 & 2 & 3 & 2 & 6 & 1 & 7 \\
\hline
\end{tabular}


hemorrhage and cerebrospinal fluid leakage. Moreover, postoperative complications include epistaxis, medial rectus palsy, progressive closure of the ostium, development of adhesions, granuloma formation, orbital/subcutaneous emphysema, hematoma, synechia, canalicular stenosis and conjunctival fistula. ${ }^{[1]}$

Varying results have been reported for endoscopic DCR; however, Onerci et al. ${ }^{[21]}$ indicated that the surgical success rate of endoscopic DCR in the hands of experienced surgeons was $94.4 \%$, whereas inexperienced surgeons had a success rate of only 58 percent. ${ }^{[2]}$

Many factors influence the success or failure of DCR. Regarding improved surgical success, the size and location of the osteotomy is important. ${ }^{[2]}$ Additionally, mitomycin $\mathrm{C}$ has been reported to delay wound healing or prevent scarring at the ostial opening. ${ }^{[2]}$ Furthermore, the distal canalicular membranous obstruction is an anatomic factor that may lead to surgical failure if not identified and excised and in these cases, an external DCR procedure combined with membranectomy performed through the distal canalicular opening is recommended. ${ }^{[23]}$

Laser-assisted DCR is an alternative to the standard external DCR..$^{[4]}$ In DCR, argon, potassium titanyl phosphate (KTP): YAG, holmium: YAG, neodymium: YAG and multidiode lasers are used. ${ }^{[3]}$

The principle of the multidiode laser is based on absorption of its energy by the target tissue and transformation of this energy into a thermal effect. This effect creates an incision in the mucosa and bone in order to construct a fistula between the lacrimal sac and nasal cavity. ${ }^{[24]}$ The neo-ostium can be enlarged by laser application, or after the initial laser application, with a crescent knife and ethmoid forceps. Bone-cutting forceps are not required because the diode laser can be applied to ablate the bone. ${ }^{[25]}$ The laser systems achieve satisfactory coagulation and postsurgical edema is not seen with diode laser application. This advantage provides lesser intraoperative bleeding and results in faster wound healing. ${ }^{[24]}$ As stated in the results section, preoperative and postoperative bleeding were significantly less frequent in the laser group than in the endonasal group $(\mathrm{p}<0.005)$.

To avoid obstruction of the neo-ostium, the sac should be opened as widely as possible during surgery, ${ }^{[26]}$ an adequate amount of bone should be removed and silicon tubing should be inserted. ${ }^{[27]}$ Furthermore, application of mitomycin $\mathrm{C}$ on the lacrimal opening at the end of the procedure ${ }^{[28]}$ and performing concomitant nasal procedures such as a partial middle turbinectomy ${ }^{[2]]}$ may help increase the success rate in cases of endocanalicular diode laser DCR. ${ }^{[2]}$ Wormald et al. ${ }^{[26]}$ showed that the major portion of the sac was situated above the middle turbinate and that inadequate bone removal above the middle turbinate is an important reason for failure in all treatment approaches to nasolacrimal ductus obstruction. ${ }^{[25]}$

The endocanalicular approach usually creates smaller neo-ostia than the external and endonasal approaches and this is correlated with lower success rates of endocanalicular DCR. ${ }^{[30]}$ Other reasons for failure of endocanalicular diode laser application are related to formation of synechia between the lateral surface of the middle turbinate and the medial surface of the lateral wall of the nose and the granulation tissue obstructing the neo-ostium. ${ }^{[25]}$

In one study, a gel foam patch was packed to keep the neo-ostium open throughout the healing period after endonasal DCR. ${ }^{[3]}$ In another study, the uncinate process was evaluated as a landmark and unciformectomy was found to affect the success rate and complications of endonasal DCR. Anterior resection of the uncinate process is important for exposing the precise location of the osteotomy on the lacrimal bone during endonasal DCR. ${ }^{[1]}$

During follow-ups, synechia formation and failures were more frequently seen in Group 1 and seemed to be the main underlying pathology for the failures in this group.

In our study, all the nine recurrent cases in Group 1 were reoperated. There were six recurrent cases in Group 2 and only 2 of them needed reoperation. Because SF passed through the nasal cavity and the ostium was opened endoscopically, reoperation was not recommended in other 4 recurrent cases of Group 2. It was surmised that recurrences were due to reduced pumping function of the sac or canaliculus and a problem in the common canal.

In Group 1, complications included formation of synechia between the lateral surface of the middle turbinate and the medial surface of the lateral wall of the nose and silicone tube protrusions. Synechia formation was considered to be due to contact of the hypertrophic turbinates at the surgical site, thereby damaging the nasal mucosa during endoscopic surgery. Silicone tube protrusions from the punctum were determined to be due to loose knots.

When the middle turbinate is tampered and more laser energy is applied, the nasal mucosa is not protected from the effects of vaporization, resulting in synechia formation.

Punctum atrophy was seen in two cases which did not cause a significant problem. We determined that this complication was due to constriction of the punctum with a 
tight knot. In two cases we observed silicone tube protrusion due to inadequate tension of the knot, entering inside the little knot after large opening of the ostium and patient's scratching his/her eyes.

When the association between the incidence rates of recurrence, complications and allergy was evaluated, there was no significant difference between the groups. Likewise, the rate of recurrence and complications was not significantly associated with the presence of concha hypertrophy. Similarly, the presence of septum deviation did not significantly increase the rate of recurrence or complications. These non-significant associations may be due to an insufficient number of patients.

\section{Conclusion}

Postoperative comfort in patients who received endocanalicular diode laser DCR (Group 2) was better than that in patients in the endonasal group (Group 1) because the former procedure did not require packing. The healing time was shorter, postoperative pain was lower and bleeding episodes were decreased during and after surgery in the endocanalicular diode laser DCR patient group compared to the endonasal DCR group. These results demonstrate that the diode laser is a good alternative for DCR surgery. As our study group is relatively small, further studies are needed to compare these two treatment modalities.

\section{Acknowledgement}

We thank "Bülent Tuncel, MD" and "Zeki Ermiş, MD" for their contribution.

Conflict of Interest: No conflicts declared.

\section{References}

1. Yang JW, Oh HN. Success rate and complications of endonasal dacryocystorhinostomy with unciformectomy. Graefes Arch Clin Exp Ophthalmol 2012;250:1509-13.

2. Preechawai P. Results of non endoscopic endonasal dacryocystorhinostomy. Clin Ophthalmol 2012;6: 1297-301.

3. Cakmak SS, Yildirim M. Use of endocanalicular dacryocystorhinostomy with multidiode laser in children. Int J Pediatr Otorhinolaryngol 2010;74:1320-2.

4. Plaza G, Beteré F, Nogueira A. Transcanalicular dacryocysto rhinostomy with diode laser: long-term results. Ophthalmic Plast Reconstr Surg 2007;23:179-82.

5. Mirza S, Jones N. Laser-assisted dacryocystorhinostomy. In: Weber RK, Keerl R, Schaefer SD, editors. Atlas of lacrimal surgery. Heidelberg: Springer-Verlag: 2007. p. 73-85.

6. Piaton JM, Keller P, Limon S, Quenot S. First line endonasal dacryocystorhinostomy technique and results. Comparison between diode laser and electrocautery instrument. Study based on 422 procedures. [Article in French] J Fr Ophtalmol 2002;25: $135-45$.

7. Eloy P, Leruth E, Cailliau A, Collet S, Bertrand B, Rombaux P. Pediatric endonasal endoscopic dacryocystorhinostomy. Int J Pediatr Otorhinolaryngol 2009;73:867-71.

8. Watkins LM, Janfaza P, Rubin PA. The evolution of endonasal dacryocystorhinostomy. Surv Ophthalmol 2003;48:73-84.

9. Fayet B, Racy E, Assouline M. Complications of standardized endonasal dacryocystorhinostomy with unciformectomy. Ophthalmology 2004;111:837-45.

10. Hartikainen J, Antila J, Varpula M, Puukka P, Seppä H, Grénman R. Prospective randomised comparison of endonasal endoscopic dacryocystorhionstomy and external dacryocystorhinostomy. Laryngoscope 1998;108:1861-6.

11. Boush GA, Lemke BN, Dortzbach RK. Results of endonasal laserassisted dacryocystorhinostomy. Ophthalmology 1994;101:955-9.

12. Hausler R, Caversaccio M. Microsurgical endonasaldacryocystorhinostomy with long-term insertion of bicanalicular silicone tubes. Arch Otolaryngol Head Neck Surg 1998;124:188-91.

13. Athanasiov PA, Prabhakaran VC, Mannor G, Woog JJ, Selva D. Transcanalicular approach to adult lacrimal duct obstruction: a review of instruments and methods. Ophthalmic Surg Lasers Imaging 2009;40:149-59.

14. Narioka J, Ohashi Y. Dacryocystography with nasolacrimal probing under fluoroscopic guidance for treatment of congenital dacryocystocele. J AAPOS 2008;12:299-301.

15. MacEwen CJ, Young JDH. Epiphora during the first year of life. Eye 1991;5:596-600.

16. Petersen RA, Robb RM. The natural course of congenital obstruction of the nasolacrimal duct. J Pediatr Ophthalmol Strabismus 1998;15:246-50.

17. Paysse EA, Coats DK, Bernstein JM, Go C, De Jong AL. Management and complications of congenital dacryocele with concurrent intranasal mucocele. J AAPOS 2000;4:46-53.

18. Hurwitz JJ, Welham AN. The role of dacryocystography in the management of congenital nasolacrimal duct obstruction. Can J Ophthalmol 1975;10:346-50.

19. O’Donell BA, Adenis JP, Linberg JV, Rose GE, Suillivan TJ, Wobig JL. The failed probing. Clin Exp Ophthalmol 2001;29: 276-80.

20. Karim R, Ghabrial R, Lynch T, Tang B. A comparison of external and endoscopic endonasal dacryocystorhinostomy for acquired nasolacrimal duct obstruction. Clin Ophthalmol 2011;5:979-89.

21. Onerci M, Orhan M, Ogretmenoglu O, Irkec M. Long-term results and reasons for failure of intranasal endoscopic dacryocystorhinostomy. Acta Otolaryngol 2000;120:319-22.

22. Lee S, Yen MT. Laser-assisted dacryocystorhinostomy: a viable treatment option? Curr Opin Ophthalmol 2011;22:413-8.

23. Boboridis KG, Bunce C, Rose GE. Outcome of external dacryocystorhinostomy combined with membranectomy of a distal canalicular obstruction. Am J Ophthalmol 2005;139:1051-5.

24. Alaňón Fernández MA, Alaňón Fernández FJ, Martínez Fernández A, et al. Endonasal and endocanalicular dacryocystorhinostomy by diode laser. Preliminary results. [Article in Spanish] Acta Otorrinolaringol Esp 2004;55:171-6. 
25. Basmak H, Caklı H, Sahin A, et al. Comparison of endocanalicular laser dacryocystorhinostomy with and without endonasal procedures. Graefes Arch Clin Exp Ophthalmol 2011;249:737-43.

26. Wormald PJ, Kew J, Van Hasselt A. Intranasal anatomy of the nasolacrimal sac in endoscopic dacryocystorhinostomy. Otolaryngol Head Neck Surg 2000;123:307-10.

27. Unlu HH, Toprak B, Aslan A, Guler C. Comparison of surgical outcomes in primary endoscopic dacryocystorhinostomy with and without silicone intubation. Ann Otol Rhinol Laryngol 2002;111: 704-9.
28. Selig YK, Biesman BS, Rebeiz EE. Topical application of mitomycin-C in endoscopic dacryocystorhinostomy. Am J Rhinol 2000; 14:205-7.

29. Fayet B, Racy E, Assouline M. Systematic unciformectomy for a standardized endonasaldacryocystorhinostomy. Ophthalmology 2002;109:530-6.

30. Rosen N, Barak A, Rosner M. Transcanalicular laser assisted dacryocystorhinostomy. Ophthalmic Surg Lasers 1997;28:723-6.

31. Hong-Ryul J, Je-Yeob Y, Mi-Young C. Endoscopic dacryocystorhinostomy: creation of a large marsupialized lacrimal sac. J Korean Med Sci 2006;21:719-23.

This is an open access article distributed under the terms of the Creative Commons Attribution-NonCommercial-NoDerivs 3.0 Unported (CC BYNC-ND3.0) Licence (http://creativecommons.org/licenses/by-nc-nd/3.0/) which permits unrestricted noncommercial use, distribution, and reproduction in any medium, provided the original work is properly cited.

Please cite this article as: Acar M, Gören F, Yazıcı D, Yıldırım G, San T. Comparison of endonasal dacryocystorhinostomy (DCR) versus endocanalicular diode laser DCR for the treatment of nasolacrimal duct obstruction. J Med Updates 2014;4(3):87-93. 